\title{
GAYA BELAJAR MAHASISWA KEPERAWATAN UNIVERSITAS ISLAM NEGERI ALAUDDIN MAKASSAR
}

\author{
Risnah $^{1}$, Astuti Dewi Intan ${ }^{2}$ \\ 1,2Fakultas Kedokteran dan Ilmu Kesehatan UIN Alauddin Makassar \\ 1,2Kampus: Jalan H.M. Yasin Limpo Nomor 36 Samata-Gowa, Sul-Sel \\ E-mail: risnah_ina@yahoo.com
}

\begin{abstract}
Abstrak:
Penelitian ini bertujuan untuk memberikan gambaran gaya belajar peserta didik yang berprestasi akademik tertinggi dan terendah pada Mahasiswa Keperawatan Universitas Islam Negeri Alauddin Makassar. Jenis penelitian deskriptifdengan pendekatan kualitatif. Informan adalah mahasiswa keperawatan yang memiliki prestasi akademik tertinggi dan terendah pada setiap angkatan yang berjumlah delapan orang, yaitu lima orang mahasiswa berprestasi akademik tertinggi dan tiga orang mahasiswa berprestasi akademik terendah. Pengumpulan data melalui observasi berperan serta, wawancara mendalam, dan studi dokumen. Teknik analisis data adalah teknik analisis isi (content analysis) dengan melalui tahap pengumpulan, membuat transkrip data, menentukan makna unit, meringkas dan mengorganisir data, melakukan abstraksi data, mengidentifikasi variabel dan hubungan atar variabel secara kualitatif dan menarik kesimpulan. Peneliti menggunakan uji konfirmabilitas dilakukan dengan pelampiran berbagai data-data yang diperoleh saat penelitian. Hasil penelitian menunjukkan bahwa mahasiswa keperawatan yang berprestasi akademik tertinggi dan terendah masing-masing menunjukkan kombinasi gaya belajar visual, auditori dan kinestik dengan kecenderungan gaya belajar yang berbeda.
\end{abstract}

\begin{abstract}
:
This study aims to provide the description of the learning styles of students with the highest and the lowest academic achievement of Nursing Students of Islamic Alauddin State Islamic University Makassar. This was a qualitative approach. The participants were eight nursing students. Five students who had the highest and three students who had the lowest academic achievement in each academic year. The data collected through observation, in-depth interviews, and document studies. The technique of data analysis was content analysis, which was done by going through the stages of data collection, creating transcripts of the data, determining the unit meaning, summarizing and organizing the data, performing data abstraction, identifying variables and the relationship between variables qualitatively, and drawing a conclusion. The researcher used conformability test which was done by presenting various data obtained at the time of the study. The results of the study showed that the students with the highest and the lowest academic achievement showed a combination of visual, auditory, and kinesthetic with variations.
\end{abstract}

Kata kunci:

Gaya Belajar, Mahasiswa Berprestasi Akademik Tertinggi Dan Terendah

SEBAGAI profesi, keperawatan dituntut untuk memiliki kemampuan intelektual, interpersonal kemampuan teknis, dan moral. Hal ini bisa ditempuh dengan meningkat- 
kan kualitas perawat melalui pendidikan keperawatan (S1). Dengan demikian, diharapkan terjadi perubahan yang mendasar dalam upaya berpartisipasi aktif untuk menyukseskan program pemerintah dan berwawasan yang luas tentang profesi keperawatan. Perubahan tersebut bisa dicapai apabila pendidikan tinggi keperawatan tersebut dilaksanakan dengan memperhatikan perkembangan pelayanan dan program pembangunan kesehatan seiring dengan perkembangan iptek bidang kesehatan serta diperlukan proses pembelajaran baik institusi pendidikan maupun pengalaman belajar klinik di rumah sakit dan komunitas.

Gaya belajar adalah cara yang lebih disukai dalam melakukan kegiatan berpikir, memproses, dan mengerti suatu informasi (Adi W. Gunawan, 2008: 139). Gaya belajar antar peserta didik belum tentu sama. Rita Dunn menyatakan bahwa setiap manusia memiliki gaya belajar yang unik dan gaya tersebut khas sebagaimana tanda tangan (Gordon dan Jeannette, 2008: 340). Keunikan gaya belajar peserta didik dapat menjadi referensi dosen dalam menentukan metode pembelajaran yang bervariasi.

Kesesuaian antara gaya mengajar dosen dengan gaya belajar peserta didik mempengaruhi prestasi akademik peserta didik. Hasil riset menunjukkan bahwa peserta didik yang belajar dengan menggunakan gaya belajar mereka yang dominan, saat mengerjakan tes, akan mencapai nilai yang jauh lebih tinggi dibandingkan bila mereka belajar dengan cara yang tidak sejalan dengan gaya belajar mereka (Adi W. Gunawan, 2008: 139). Dengan demikian, keselarasan gaya mengajar dosen dengan gaya belajar peserta didik dapat meningkatkan prestasi akademik peserta didik.

Sesuai dengan gambaran masalah belajar yang telah dikemukakan di atas, peneliti tertarik untuk mempelajari gaya belajar peserta didik tersebut dengan asumsi dasar bahwa gaya belajar mempengaruhi prestasi akademik peserta didik. Adapun penelitian akan dilakukan pada Mahasiswa keperawatan yang memiliki prestasi akademik tertinggi dan terendah di Fakultas Kedokteran dan Ilmu Kesehatan Universitas Islam Negeri Alauddin Makassar.

\section{TINJAUAN TEORETIS}

\section{Gaya Belajar}

\section{Pengertian Belajar}

Dalam aktivitas kehidupan manusia sehari-hari hampir tidak pernah terlepas dari kegiatan belajar, baik ketika seseorang melaksanakan aktivitas sendiri, maupun di dalam suatu kelompok tertentu. Dipahami ataupun tidak dipahami, maupun di dalam suatu kelompok tertentu. Dipahami ataupun tidak dipahami, sesungguhnya sebagian besar aktivitas di dalam kehidupan sehari-hari kita merupakan kegiatan pembelajaran. Dengan demikian dapat kita katakan, ada ruang dan waktu dimana manusia dapat melepaskan dirinya dari kegiatan belajar, dan itu berarti pula bahwa belajar tidak pernah dibatasi usia, tempat maupun waktu, karena perubahan yang menuntut terjadinya aktivitas belajar juga tidak pernah berhenti. 


\section{Pengertian Gaya Belajar}

Para peneliti menggunakan istilah yang berbeda dan menemukan berbagai cara untuk mengatasi gaya belajar peserta didik, telah disepakati secara umum adanya dua kategori utama tentang bagaimana mahasiswa belajar. Pertama, bagaimana mahasiswa menyerap informasi dengan mudah dan kedua, cara mahasiswa mengatur dan mengolah informasi tersebut. Gaya belajar adalah kombinasi dari bagaimana ia menyerap dan kemudian mengatur serta mengolah informasi.

\section{Macam-Macam Gaya Belajar}

Pada awal pengalaman belajar, salah satu diantara langkah-langkah pertama kita adalah mengenali modalitas seseorang sebagai modalitas visual, auditorial, atau kinestetik (V-A-K). Seperti yang telah diusulkan istilah-istilah ini, orang visual belajar melalui apa yang mereka lihat, pelajar auditorial melakukannya melalui apa yang mereka dengar, dan pelajar kinestetik belajar melalui gerak dan sentuhan. Walaupun masing- masing dari kita belajar dengan menggunakan ketiga modalitas ini pada tahap tertentu, kebanyakan orang lebih cenderung pada salah satu diantara ketiganya. Secara umum terdapat 3 gaya belajar, yaitu:

1. Gaya belajar visual

2. Gaya belajar auditorial

3. Gaya Belajar Kinestik

\section{Karakteristik Gaya Belajar Visual, Auditori dan Kinestik}

Peserta didik memiliki kombinasi gaya belajar visual, auditori dan kinestetik, tetapi cenderung pada satu gaya belajar tertentu dibandingkan dua gaya lainnya. Setiap gaya belajar memiliki karakteristik atau ciri khas masing-masing gaya belajar. Karakteristik gaya belajar bersifat alami, jika dipaksakan akan menimbulkan ketidaknyamanan dan frustasi.

Adapun karakteristik gaya belajar kinestetik yaitu: (a) menempatkan tangan sebagai alat penerima informasi utama agar bisa mengingat, (b) dengan memegang bisa menyerap informasi tanpa harus membaca penjelasan, (c) tidak bisa/tahan duduk terlalu lama untuk mendengarkan pelajaran, (d) merasa bisa belajar lebih baik apabila disertai dengan kegiatan fisik, (e) mampu mengoordinasikan sebuah tim dan mengendalikan gerakan tubuh (athletic ability).

\section{Peserta Didik Berprestasi Akademik}

Peserta didik diartikan sebagai anggota masyarakat yang berusaha mengembangkan potensi diri melalui pendidikan (Arif Rohman, 2009: 105). Dosen perlu memahami bahwa semua peserta didik memiliki kebutuhan meskipun intensitas antar peserta didik. Dengan mengenali gaya belajar peserta didik, maka akan membuat proses belajar mengajar jauh lebih efektif dan efisien sehingga menimbulkan pengaruh yang besar terhadap prestasi belajar mereka.

Sesuai dengan ketentuan sistem kredit semester (SKS) yang berlaku di perguruan tinggi, ada tiga hal penting yang merupakan pokok-pokok pengertian yang berkaitan dengan masalah hasil belajar sebagai prestasi akademik. 
1. Penilaian hasil belajar dinyatakan dengan huruf $A, B, C, D$ dan $E$ yang masing-masing memiliki bobot 4,3,2,1 dan 0 .

2. Syarat kelulusan program ditetapkan atas pemenuhan jumlah SKS yang di isyaratkan dan indeks prestasi komulatif (IPK) minimum.

3. Penialaian terhadap hasil belajar mahasiswa dilakukan secara menyeluruh dan berkesinambungan dengan cara yang sesuai dengan karakteristik pendidikan yang bersangkutan.

4. Indeks prestasi komulatif (IPK) merupakan indikator dari hasil belajar mahasiswa dalam satu atau lebih semester yang diperoleh dengan jalan membagi jumlah nlai tersebut dengan jumlah sks. Oleh karena itu, SKS yang dipakai sebagai penentu belajar mahasiswa.

\section{METODE PENELITIAN}

\section{Waktu dan Tempat Penelitian}

Penelitian dilaksanakan pada tanggal 10 April - 10 Mei 2017. Penelitian ini dilaksanakan di Fakultas Kedokteran dan Ilmu Kesehatan Universitas Islam Negeri Alauddin Makassar pada Jurusan Keperawatan.

\section{Populasi dan Sampel}

Sampel dalam penelitian kualitatif bukan dinamakan responden, tetapi sebagai narasumber, partisipan, informan dalam penelitian. Dalam penelitian ini terdapat 8 orang informan. Teknik pengambilan sampel adalah Non Probability Sampling jenis Purposive Sampling. Menurut Nursalam (2008), Non Probability Sampling jenis Purposive Sampling yaitu tehnik penetapan sampel dengan cara memilih sampel diantara populasi sesuai dengan yang dikehendaki peneliti sehingga sampel tersebut dapat mewakili karakteristik populasi yang telah dikenal sebelumnya (Nursalam, 2008). Kriteria sampel dalam penelitian ini adalah:

1. Mahasiswa keperawatan yang masih aktif kuliah dan telah melalui berbagai mata kuliah, mulai dari mata kuliah dasar hingga mata kuliah khusus keperawatan yang memiliki tingkat kesulitan yang berbeda-beda.

2. Mahasiswa keperawatan yang memiliki prestasi akademik tertinggi dan terendah pada setiap angkatan.

\section{HASIL DAN PEMBAHASAN}

\section{Gambaran Umum Lokasi Penelitian}

Universitas Islam Negeri Alauddin Makassar adalah salah satu perguruan Tinggi Islam Negeri yang terbesar di kawasan Indonesia timur yang terletak di sulawesi selatan kota Makassar kabupaten Gowa Kel. Romang Polong tepatnya di Samata. Perguruan Tinggi Islam yang mengawali namanya IAIN Alauddin yang terletak di Jl. Sultan Alauddin Makassar itu kini telah menjadi Universitas dengan jumlah Mahasiswa yang setiap tahun semakin meningkat dengan pesat dan hal itupulalah yang men- 
dorong pemerintah untuk menjadikan perguruan tinggi islam itu menjadi Universitas Islam Negeri Alauddin Makassar atau yang sekarang sering disebut UIN.

\section{Keadaan Geografis dan Luas Wilayah}

UIN Alauddin Makassar yang terletak di samata gowa itu yang luas kampus II, Samata Gowa Kel. Romang Polong 32.000 m2 dengan jumlah gedung perkuliahan yang terdiri dari delapan Fakultas yang dimana fakultas Ilmu Kesehatan Sendiri memiliki luas wilayah 1.057,18 m2 yang berdiri empat gedung perkuliahan dan memiliki lima jurusan.

\section{Suasana Fakultas Kedokteran dan Ilmu Kesehatan}

Dengan konsep bagunan yang bergaya arsitek Mesir itu tanpak indah dan megah dengan balutan cat warna coklat mudah dengan tatanan gedung yang berdiri rapih di lingkungan yang asri dan hijau.

\section{Sarana dan Prasarana}

Di fakultas ilmu kesehatan sebagian ruang kelas dilengkapi dengan AC dan proyektor untuk mendungkung proses belajar mengajar mahasiswa, dan juga laboratorium yang dilengkapi dengan fasilitas kebutuhan belajar mahasiswa seperti buku, pantom, dan alat-alat medis lainya, sebuah perpustakaan, musolah, kelas teater (Lt) dan dipermudah dengan adanya jaringan wifi yang setiap saat dapat digunakan mahasiswa untuk mencari tugas-tugas yang diberikan oleh dosen.

\section{Proses Belajar Mengajar}

Jumlah SKS pada jurusan keperawatan dari semester 1-8 yaitu 148 sks. Pengajuan judul skripsi dimulai pada semester 5 dan proses penyusunan skripsi di mulai pada semester 6. Matakuliah terkait dengan skripsi dimulai dengan matakuliah metodologi penelitian pada semester 5 dan dilanjutkan pada semester 6 dengan matakuliah riset keperawatan

\section{Gambaran Hasil Penelitian dan Pembahasan}

Berdasarkan hasil penelitian ditemukan dua temuan. Pertama, mahasiswa keperawatan yang berprestasi akademik tertinggi dan terendah menunjukkan kombinasi gaya belajar visual, auditori dan kinestik (gaya belajar vak). Kedua, mahasiswa keperawatan yang berperestasi akademik tertinggi dan terenadah menunjukkan kecenderungan gaya belajar yang berbeda. Berdasarkan temuan pertama, mahasiswa keperawatan yang berprestasi akademik tertinggi maupun terendah tidak menunjukkan satu gaya belajar saja, melainkan kombinasi gaya belajar visual, auditori, dan kinestik. Mahasiswa keperawatan belajar tidak hanya dengan membaca, tetapi menulis (membuat catatan materi pembelajaran) sekaligus menyimak apa yang dosen jelaskan. Mahasiswa keperawatan menghapal dengan mengulangi bacaan, mengeraskan suara, senang berdiskusi dengan teman-teman atau bertanya pada dosen serta aktif bergerak ketika belajar maupun pada saat menghapal. Temuan ini sesuai dengan pernyataan 
Bobby DePorter dkk (2013: 85), Suyono dan Hariyanto (2012: 149), serta Adi W. Gunawan (2007: 87) yang meyatakan bahwa peserta didik memiliki gaya belajar visual, auditori dan kinestik.

Mahasiswa keperawatan yang memiliki prestasi akademik tertinggi dan terendah belajar dengan mendengarkan, melihat vidio, menulis dan bergerak. Mahasiswa aktif bertanya dan melakukan diskusi dengan teman. Mahasiswa keperawatan senang menunjukkan tangan pertama kali ketika dosen bertanya, praktek, serta melakukan katifitas fisik, seperti mengetukkan jari atau kaki. Hal tersebut sesuai dengan pernyataan Colin Rose dan Malcolmm J. Marshall (2009: 126) bahwa peserta didik yang berprestasi tidak pernah duduk dengan pasif hanya dengan mendengarkan atau membaca saja. Peserta didik senantiasa bergerak dan melakukan berbagai aktifitas belajar.

Karakteristik gaya belajar yang muncul pada satu mahasiswa keperawatan belum tentu muncul pada gaya belajar mahasiswa keperawatan yang beprestasi akademik tertinggi maupun terendah yang lain. MS ketika ingin belajar di luar kelas memilih untuk belajar di perpustakaan, tetapi ciri tersebut tidak ditunjukkan oleh mahasiswa keperawatan yang lain. AN ketika ingin menghapal suatu materi pelajaran biasanya sambil mendengarkan musik. AR suka belajar melalui praktek. MA suka menjelaskan dengan menuliskan di kertas atau papan tulis. HD menyukai cara mengajar dosen yang menjelaskan langsung. LA akan memilih sendiri jika ingin belajar atau membaca di luar kelas. AK ketika menjelaskan senang berbicara atau menjelaskan panjang lebar dan NA suka mengerjakan tugas sambil membaca. Hasil penelitian tersebut sesuai dengan pernyataan Rita Dunn (Gordon dan Jeannete, 2009: 340) bahwa setiap peserta didik mempunyai gaya belajar yang unik, serta pernyataan Sugihartono (2007: 53), gaya belajar efektif untuk seseoramg peserta didik, tetapi belum tentu efektif untuk peserta didik lain.

Gaya belajar yang muncul merupakan kebiasaan-kebiasaan mahasiswa keperawatan yang berperestasi akademik tertinggi maupun mahasiswa keperawatan yang memiliki prestasi akademik terendah. Ada mahasiswa yang ketika ingin menghapal suatu materi pelajaran harus membaca sambil mengeraskan suara, ada pula yang ketika menghapal cukup membacanya saja secara berulang-ulang, serta ada yang ketika menghapal harus bergerak (mondar-mandir) sambil membaca. Hasil penelitian ini sesuai dengan pernyataan Popi dan Sohari (2011: 37) bahwa gaya belajar merupakan kebiasaan yang dipilih peserta didik dalam belajar, baik di dalam kelas maupun di lingkungan terbuka.

Pada temuan kedua, mahasiswa keperawatan yang berprestasi akademik tertinggi maupun terendah menunjukkan perpaduan gaya belajar dengan kecenderungan gaya belajar yang berebeda. Ada mahasiswa keperawatan yang berperestasi akademik tertinggi maupun terendah yang lebih banyak menunjukkan karakteristik gaya belajar auditori, tetapi ada pula yang cenderung menunjukkan karakteristik gaya belajar visual. Temuan ini sesuai dengan pendapat Bobby DePorter dkk (2013 : 85), serta Popi dan sohari (2011: 36), Bahwa dalam kenyataannya peserta didik memiliki ketiga gaya belajar, hanya saja biasanya cenderung pada satu gaya belajar tertentu. 
Hasil penelitian ini juga menyatakan bahwa mahasiswa keperawatan yang berprestasi akademik tertinggi dan terendah masing-masing menunjukkan kombinasi gaya belajar VAK (visual, auditori dan kinestik) namun dengan kecendrungan gaya belajar yang berbeda. Kecenderungan gaya belajar mahasiswa keperawatan yang berprestasi akademik tertinggi, dua dari lima orang mahasiswa keperawatan yang berprestasi akademik tertinggi cenderung menggunakan gaya belajar visual dengan komposisi dari urutan terbanyak visual > auditori > kinestik, sedangkan tiga orang lainnya cenderung pada gaya belajar auditori namun dengan komposisi urutan terbanyak yang berbeda yaitu dua orang dengan komposisi terbanyak auditori $>$ visual $>$ kinestik sedangkan satu orang lagi cenderung menggunakan gaya belajar auditori pada komposisi auditori $>$ visual = kinestiknya. Sedangkan tiga mahasiswa keperawatan yang berprestasi akademik terendah, dua diantaranya cenderung menggunakan gaya belajar visual dengan komposisi dari urutan terbanyak berbeda yaitu visual $>$ auditori $>$ kinestik dan visual $>$ kinestik $>$ Auditori. Satu orang lagi mahasiswa dengan prestasi akademik terandah cenderung menggunakan gaya belajar auditori dengan komposisi yaitu auditori > visual > kinestik. Komposisi gaya belajar dari urutan terbanyak pada setiap mahasiswa keperawatan, yakni:

1. Mahasiswa Keperawatan Berprestasi Akademik Tertinggi

a. $\mathrm{MS}=$ Auditori $>$ visual dan kinestik

b. $\mathrm{AN}$ dan $\mathrm{AK}=$ Visual $>$ auditori $>$ kinestik

c. MA dan $\mathrm{LA}=$ Auditori $>$ visual $>$ kinestik

2. Mahasiswa Keperawatan Berprestasi Akademik Terendah

a. $\mathrm{NA}=$ Visual $>$ auditori $>$ kinestik

b. $\mathrm{AR}=$ Visual $>$ kinestik $>$ Auditori

c. $\mathrm{HD}=$ Auditori $>$ visual $>$ kinestik

Hasil tersebut tidak sesuai dengan pernyataan Colin Rose dan Malcolm J. Marsall (2009: 131) bahwa kecenderungan gaya belajar selalu meningkat dari gaya belajar visual ke gaya belajar kinsetik (visual> auditori> kinestik) Pada penelitian ini, masing-masing gaya belajar visual, auditori dan kinestik menempati urutan kedua apapun kecenderungan gaya belajar yang mahasiswa keperawatan gunakan.

Kecenderungan karakteristik gaya belajar vak pada ke delapan peserta didik yang berprestasi akademik tertinggi maupun terendah menggambarkan beberapa karakteristik setiap gaya belajar yakni: gaya belajar visual pada mahasiswa keperawatan a) belajar melalui proses melihat vidio, mencatat dan membaca buku, b) tidak pandai memilih kata-kata, c) senang menjawab dengan jawaban singkat dan menjelaskan sambil menuliskan, d) tempo bicara cepat, e) menghapal dengan cara mengulangi bacaan, f) mengerjakan tugas sambil membaca dan mengikuti petunjuk terlebih dahulu, g) mudah mengingat wajah, h) menyukai cara mengajar dosen yang menggunakan media alat (vidio dan power point ), i) tempo bicara ceapat, j) gerakan bola mata ke atas dan k) menyukai seni lukis. Gaya belajar auditori pada mahasiswa keperawatan a) belajar dengan mendengarkan dan berdiskusi, b) menghapal dengan mengeraskan suara dan sambil mendengarkan musik, c) tempo bicara lambat, d) melakukan komu- 
nikasi internal, e) mudah terganggu oleh keributan, f) mengingat info lisan, g) suka dengan metode mengajar dosen yang menjelaskan langsung (ceramah), h) gerakan bola mata ke samping (sejajar telinga), i) berbicara dengan jeda yang jelas dan, j) menyukai seni musik. Gaya belajar kinestik a) belajar melalui praktek dan simulasi, b) menggunakan isyarat tubuh saat menjelaskan, dan c) tidak bisa duduk diam dalam waktu yang lama, d) mencari tahu sambil mengerjakan tugas, e) mudah mengingat hal-hal yang dilakukan bersama, f) suka metode mengajar dosen yang memberikan contoh dan menggambarkan langsung, g) mengetukkan jari/kaki atau benda pada saat belajar, h) gerakan bola mata ke bawah atau menunduk, i) aktif bertanya atau menjawab, i) tulisan kurang bagus dan, j) menyukai seni tari. Hasil penelitian ini sesuai dengan pernyataan Colin Rose dan Malcolm J. Nicholl (2009: 126) yang menyatakan bahwa pembelajar sukses senantiasa belajar dengan aktif, bertanya pada diri sendiri, serta melakukan berbagai aktifitas belajar sesuai dengan pilihan indranya. Tentu saja, peserta didik memperlihatkan ketiga karakteristik gaya belajar vak (2009: 135). Pada dasarnya hakikat dari panca indra adalah untuk mencari kebenaran yang bersifat ilmiah, namun dalam Al-Quran hakikat panca indra bukan semata-mata untuk mencari kebenaran melainkan untuk mencari tanda-tanda, kebajikan-kebajikan dan rahmah. Hal ini sesuai dengan firman Allah Swt dalam QS AL A'raaf / 7: 179, yang artinya:

Dan Sesungguhnya Kami jadikan untuk (isi neraka Jahannam) kebanyakan dari jin dan manusia, mereka mempunyai hati, tetapi tidak dipergunakannya untuk memahami (ayat-ayat Allah) dan mereka mempunyai mata (tetapi) tidak dipergunakannya untuk melihat (tanda-tanda kekuasaan Allah), dan mereka mempunyai telinga (tetapi) tidak dipergunakannya untuk mendengar (ayat-ayat Allah). mereka itu sebagai binatang ternak, bahkan mereka lebih sesat lagi. Mereka Itulah orang-orang yang lalai".

Ayat di atas menjelaskan bahwa syukurilah nikmat panca indra yang ada pada$\mathrm{mu}$, karena tidak semua orang beruntung memiliki panca indra yang berfungsi sempurna. Bersyukur yang dimaksud yaitu selalu memanfaatkan panca indra tersebut untuk hal-hal yang baik. Menggunakan lisan kita untuk mengucapkan kalimat-kalimat yang baik seperti bersalawat dan menyampaikan ilmu kepeda orang lain. Menggunakan pengelihatan kita untuk memandang hal-hal yang baik, misalnya membaca Al-Quran dan buku-buku yang bermanfaat. Juga pendengaran kita gunakan untuk mendengar hal-hal yang baik seperti mendengarkan ayat-ayat Allah dan menerima informasi dalam proses pembelajaran. Karena semua panca indra akan dimintai pertanggung jawaban dan menjadi saksi untuk apa mereka digunakan

\section{SIMPULAN}

Berdasarkan hasil penelitian yang ditemukan oleh peneliti dan sesuai dengan pembahasan pada bab sebelumnya, dapat ditarik kesimpulan bahwa:

1. Mahasiswa keperawatan yang berprestasi akademik tertinggi dan terendah menunjukkan gaya belajar vak. 
2. Kecenderungan gaya belajar mahasiswa keperawatan yang berprestasi akademik tertinggi dan terendah berbeda. Dua orang mahasiswa keperawatan yang berprestasi akademik tertinggi cenderung menggunakan gaya belajar visual dengan komposisi dari urutan terbanyak visual $>$ auditori > kinestik, sedangkan yang lain cenderung pada gaya belajar auditori dengan komposisi dari urutan terbanyak yang berbeda. Hasil penelitian ditemukan bahwa mahasiswa keperawatan yang berprestasi akademik tertinggi dan terendah masing-masing menunjukkan kombinasi gaya belajar vak (visual, auditori dan kinestik) namun dengan kecendrungan gaya belajar yang berbeda. Kecenderungan gaya belajar mahasiswa keperawatan yang berprestasi akademik tertinggi, dua dari lima orang mahasiswa keperawatan yang berprestasi akademik tertinggi cenderung menggunakan gaya belajar visual dengan komposisi dari urutan terbanyak visual $>$ auditori $>$ kinestik, sedangkan tiga orang lainnya cenderung pada gaya belajar auditori namun dengan komposisi urutan terbanyak yang berbeda yaitu dua orang dengan komposisi terbanyak auditori $>$ visual $>$ kinestik sedangkan satu orang lagi cenderung menggunakan gaya belajar auditori pada komposisi auditori $>$ visual = kinestiknya. Sedangkan tiga mahasiswa keperawatan yang berprestasi akademik terendah, dua diantaranya cenderung menggunakan gaya belajar visual dengan komposisi dari urutan terbanyak berbeda yaitu visual $>$ auditori $>$ kinestik dan visual $>$ kinestik $>$ Auditori. Satu orang lagi mahasiswa dengan prestasi akademik terandah cenderung menggunakan gaya belajar auditori dengan komposisi yaitu auditori $>$ visual $>$ kinestik.

3. Kecenderungan karakteristik gaya belajar vak pada ke delapan mahasiswa keperawatan yang berprestasi akademik tertinggi dan terendah menggambarkan beberapa karakteristik setiap gaya belajar yakni: gaya belajar visual pada mahasiswa keperawatan a) belajar melalui proses melihat vidio, mencatat dan membaca buku, b) tidak pandai memilih kata-kata, c) senang menjawab dengan jawaban singkat dan menjelaskan sambil menuliskan, d) tempo bicara cepat, e) menghapal dengan cara mengulangi bacaan, f) mengerjakan tugas sambil membaca dan mengikuti petunjuk terlebih dahulu, g) mudah mengingat wajah, h) menyukai cara mengajar dosen yang menggunakan media alat (vidio dan power point ), i) tempo bicara ceapat, j) gerakan bola mata ke atas dan k) menyukai seni lukis. Gaya belajar auditori pada mahasiswa keperawatan a) belajar dengan mendengarkan dan berdiskusi, b) menghapal dengan mengeraskan suara dan sambil mendengarkan musik, c) tempo bicara lambat, d) melakukan komunikasi internal, e) mudah terganggu oleh keributan, f) mengingat info lisan, g) suka dengan metode mengajar dosen yang menjelaskan langsung (ceramah), h) gerakan bola mata ke samping (sejajar telinga), i) berbicara dengan jeda yang jelas dan, j) menyukai seni musik. Gaya belajar kinestik a) belajar melalui praktek dan simulasi, b) menggunakan isyarat tubuh saat menjelaskan, dan c) tidak bisa duduk diam dalam waktu yang lama, d) mencari tahu sambil mengerjakan tugas, e) mudah mengingat hal-hal yang dilakukan bersama, f) suka metode mengajar dosen yang memberikan contoh dan menggambarkan langsung, g) mengetukkan jari/kaki atau benda pada saat belajar, h) gerakan 
bola mata ke bawah atau menunduk, i) aktif bertanya atau menjawab, i) tulisan kurang bagus dan, j) menyukai seni tari.

\section{DAFTAR PUSTAKA}

Al Qur'an dan Terjemahan. (2014). Departemen Agama Republik Indonesia.

Al-Hadist.

Akbar, R. (2011). Akselarasi, A-Z Informasi Program Percepatan Belajar dan Anak Berbakat Intelektual. Jakarta: PT. Gramedia.

Aunurrahman. (2011). Belajar dan Pembelajaran. Cet. V; Bandung: Alfhabeta.

Arliana, S. (2012). "Gambaran Gaya Belajar dan Indeks Prestasi Mahasiswa Akademi Keperawatan Sri Bunga Tanjung Dumai." Skripsi. Medan: Fakultas Keperawatan Universitas Sumatra Utara.

Angraini, D. K. (2013). “Film Stopmotion Tentang Doa Sehari-hari Dalam Islam”. Jurnal De sain Komunikasi Visual. Surabaya: Universitas Pembangunan Nasional Veteran.

Arifin, Z. (2012). Penelitian Pendidikan Metode dan Paradigma Baru. Bandung: Remaja Rosdakarya.

Arikunto, S. (2012). Dasar-Dasar Evaluasi Pendidikan. Edisi Revisi; Jakarta: PT. Bumi Aksara.

Azwar, S. (2010). Pengantar Psikologi Intelegensi. Yogyakarta: Pustaka Pelajar.

Bachtiar, S. (2012). Buku Pintar Memahami Psikologi Anak Didik, Cet. I; Yogyakarta: Pinang Merah Publisher.

Bakri, H. (2009). "Pemahaman Tentang Gaya Belajar." Jurnal Studia Pendidikan 1, No. 2 (2009): h. 2.

Buzan, T. Terjemahan Susi Purwoko. (2010). Buku Pintar Mind Map Untuk Anak, Jakarta: PT Gramedia Pustaka Utama.

Darmono. (2008). Perpustakaan Sekolah: Pendekatan Asfek Manajemen dan Tata Kerja, Jakarta: Grasindo.

DePorter, B. \& Mike, H. (2013) Terjemah Alwiyah Abdurrahman, Quantum Learning Membiasakan Belajar Nyaman dan Menyenangkan. Bandung: Kaifa PT Mizan Pustaka.

Dewanti, M. L. (2016). "Penerapan Model Pembelajaran Berbasis Masalah untuk Menumbuhkan Kemampuan Berpikir Kritis Siswa pada Materi Suhu dan Kalor", Skripsi, Lampung: Fakultas Keguruan dan Ilmu Pendidikan Universitas Lampung."

Dharma. (2011). Metode Penelitian pendidikan. Jakarta: Kencana.

Djamarah. (2008). Psikologi Belajar. Jakarta: Rineka Cipta.

Doantara, Y. (2016). Aktivitas dan Prestasi Belajar. http://ipotes.wordpress.com. Diakses 8 Desember 2016.

Dryner, G. \& J. Vos. (2009). Revolusi Cara Belajar (The Learning Revolution) Belajar Akan Efektif Kalau Anda Dalam Keadaan "Fun". Bandung: Penerbit Kaifa.

Ekayana, G. (2011). “Pemanfaatan Internet Sebagai Salah Satu Sumber Belajar Mahasiswa di Jurusan Teknik Elektronika." Skripsi. Yogyakarta: Fakultas Teknik Universitas Negeri Yogyakarta.

Ekowati, N. (2010). "Hubungan Antara Intelegensi Dengan Prestasi Belajar Matematika Pada Kelas IV Sekolah Dasar Condong Catur Yogyakarta Tahun Pelajaran 2009/2010." Skripsi. Yogyakarta: Fakultas Ilmu Pendidikan Universitas Negeri Yogyakarta.

Nugraheni, E. (2013). “Gaya Belajar dan Strategi Belajar Mahasiswa: Jarak Jauh Kasus di Universitas Terbuka." Jurnal Pendidikan Terbuka dan Jarak Jauh. Banten: Fakultas Keguruan dan Ilmu Pendidikan Universitas Terbuka Indonesia.

Nugraheni, N. (2014). “Peningkatan Kualitas Pembelajaran IPA Melalui Model Problem Based Learning Dengan Media Audio Visual." Skripsi. Semarang: Universitas Negeri 
Semarang: Fakultas Ilmu Pendidikan.

Fenkel \& Wallen. (2008). How to Design and Evaluate Research in Education. New York: McGrawHill.

Gunawan, A. W. (2010). Born To Be A Genios. Jakarta: Gramedia Pustaka Utama.

Hakim, T. (2014). Belajar Secara Efektif. Jakarta: Puspa Ewara.

Hamalik, O. (2011). Proses Belajar Mengajar. Jakarta: Bumi Aksara.

Hanafiah, N. \& Cucu, S. (2010). Konsep Strategi Pembelajaran, Cet. II; Bandung: Refika Aditama. Hartanti \& Nisya. (2013). Prinsip-Prinsip Dasar Keperawatan. Jakarta: Dunia Cerdas.

Haryanto \& Suyono. (2012). Belajar dan Pembelajaran, Teori dan Konsep Dasar. Bandung: PT. Remaja Rosdakarya.

Iskandar. (2012). Psikologi Pendidikan: Sebuah Orientasi Baru, Cet. I; Jakarta: Referensi.

Izzaty, R. E, dkk. (2010). Perkembangan Peserta Didik. Yogyakarta: UNY Press.

Kosmiyah, I. (2012). Belajar dan Pembelajaran, Yogyakarta: Teras.

Lestari, A. B. (2015). "Hubungan Motivasi dengan Prestasi Belajar Mahasiswa Program Sarjana Fakultas Keperawatan." Skripsi. Medan: Fakultas Keperawatan Universitas Sumatra Utara.

Linksman, R. (2014). Cara Belajar Cepat. Semarang: Dahara Prize.

Lucy. (2010). Panduan Praktis Tes Minat dan Bakat Anak. Jakarta: Penebar Plus.

Maiden, L. T. Terjemah Ivone Suryana. (2008) Fire Of Your Learning: Bangkitkan Semangat Belajar Anda, Petunjuk Belajar Yang Dipercepat untuk Usia 12 tahun ke Atas. Jakarta: PT. Gramedia Pustaka Utama.

Majid, A. (2010). Perencanaan Pembelajaran, Bandung: PT Remaja Rosda Karya.

Marsuki. (2008). Metode Penelitian Keperawatan dan Teknik Analisis Data. Jakarta: Salemba Medika.

Moleong, L. J. (2008). Metodologi Penelitian Kualitatif. Bandung: PT. Remaja Rosdakarya.

Nata, A. (2010). Tafsir Ayat-ayat Pendidikan. Jakarta: PT Raja Grafindo.

Nini, S. (2011). Rahasia Gaya Belajar Orang Besar. Yogyakarta: Javalitera.

Nursalam. (2013). Metodologi Penelitian Keperawatan, Edisi. III. Jakarta: Salemba Medika.

Nursalam. (2011). Manajemen Keperawatan. Jakarta: Salemba Medika.

Putri, M. M. (2011). “Hubungan Kecepatan Membaca dan Pemahaman Isi Bacaan dengan Indeks Prestasi Mahasiswa Keperawatan Universitas Sumatra Utara." Skripsi. Medan: Fakultas Keperawatan Universitas Sumatra Utara.

Puspitasari, J. A. (2014). "Hubungan Antara Adversity Quotiont (AQ) dengan Prestasi Belajar Mahasiswa S1 Keperawatan Fakuktas Keperawatan USU." Skripsi. Medan: Fakultas Keperawatan Universitas Sumatra Utara.

Raharja, B. (2010). “Efek Musik Terhadap Prestasi Anak Usia Pra Sekolah: Studi Komparasi Efek Lagu Anak, Dolanan Jawa, dan Musik Klasik", Jurnal Cakrawala Pendidikan. Yogyakarta: Institut Seni Indonesia Yogyakarta.

Ridwan. (2016). Ketercapaian Prestasi Belajar, http://ridwan202.wordpress.com. Diakses 7 Desember 2016.

Riyana, C. (2011). Media Pembelajaran: Hakikat, Pengembangan, Pemanfaatan dan Penilaian. Bandung: Wacana Prima.

Riyanto, Y. (2010). Paradigma Baru Pembelajaran, Cet. II; Jakarta: Prenada Medika.

Robert, S. (2012). Terjemahan Kumala Insiwi Suryo, Succesfull Lifelong Learning. Jakarta: Victory Jaya Abadi.

Rohman, A. (2010). Memahami Pendidikan dan Ilmu Pendidikan. Yogyakarta: Laksbang Mediatama. 
Rukoyah. (2014). “Pengaruh Gaya Belajar Terhadap Prestasi Belajar Peserta Didik Pada Mata Pelajaran Produktif", Journal Of Mechanical Engineering Education. Bandung: Departemen Pendidikan Teknik Mesin Universitas Pendidikan Indonesia.

Sadirman, A.M. (2011). Interaksi dan Motivasi Belajar Mengajar. Jakarta: PT Raja Grafindo.

Sahrani \& Popi. (2011). Psikologi Belajar Dalam Perspektif Islam. Bogor: Penerbit Gahlia Indonesia.

Sanjaya, W. (2010). Kurikulum dan Pembelajaran, Cet. III; Jakarta: Kencana.

Shihab, Q. (2003). Membumikan Al-Qur'an Fungsi dan Peran Wahyu Dalam Kehidupan Masyarakat. Bandung: Mizan.

Slameto. (2015). Belajar dan Faktor-faktor yang Mempengaruhi, Jakarta: Rineka Cipta.

Sudarti. (2011). "Pengaruh Gaya Belajar Terhadap Prestasi Belajar Mahasiswa Fakultas Ilmu Pendidikan Tahun ajaran 2010/2011", Skripsi. Yogyakarta: Fakultas Ilmu Pendidikan Universitas Negeri Yogyakarta.

Sudjana, N. (2011). Dasar-Dasar Proses Belajar Mengajar, Bandung: Sinar Baru Algesindo.

Sugihartono, dkk. (2008). Psikologi Pendidikan. Yogyakarta: UNY Press.

Sugiyono. (2011). Metode Penelitian Pendidikan (Penelitian Kuantitatif, Kualitatif dan R\&D). Bandung: Alfabeta.

Supriyanto, W. (2008). Teknologi Informasi Perpustakaan, Yogyakarta: Kanisius.

Surya, M. (2008). Psikologi Guru Konsep dan Aplikasi dari Guru Untuk Guru. Bandung: Alfabeta.

Susanto, A. (2013). Teori Belajar dan Pembelajaran. Jakarta: Kencana Prenada Media Group.

Syah, M. (2011). Psikologi Pendidikan. Bandung: PT. Remaja Rosdakarya.

Syamsuddin, A. M. (2008). Psikologi Kependidikan: Perangkat Sistem Pengajaran Modul. Jakarta: PT Remaja Rosdakarya.

Syamsuddin \& Vismaia. (2009). Metodologi Penelitian Pendidikan Bahasa. Bandung: Remaja Rosdakarya.

Tim Penyusun KBBI. (2012). Kamus Besar Bahasa Indonesia. KBBI offline Version 1.2.

Tobing, L. M. G. (2014). "Hubungan Perpustakaan Fakultas Keperawatan dengan Prestasi Belajar Mahasiswa Fakultas Keperawatan Universitas Sumatra Utara", Skripsi. Medan: Fakultas Keperawatan Universitas Sumatra Utara.

Tohirin. (2010). Psikologi Pembelajaran Pendidikan Agama Islam. Jakarta: Raja Grafindo Persada.

Tung, K. Y. (2015). Pembelajaran dan Perkembangan Belajar. Cet. I; Jakarta: Indeks.

Uno, H. (2010). Orientasi Baru Dalam Psikologi Pembelajaran. Jakarta: PT Bumi Aksara.

Utomo, D. (2010). Media Pembelajaran Aktif. Bandung: Nuansa Cendikia.

Panggabean, A. (2009). “Gambaran Prestasi Belajar Mahasiswa PSIK FK USU Program Reguler berdasarkan Tipe Belajar Mahasiswa." Skripsi. Medan: Fakultas Keperawatan Universitas Sumatra Utara.

Pedoman Penulisan Karya Tulis Ilmiah Makalah. (2013). Skripsi, Tesis, Disertasi dan Laporan Penelitian. Universitas Islam Negeri Alauddin Makassar.

Wasis. (2008). Pedoman Riset Praktis Untuk Profesi Perawat, Cet. I; Jakarta: ECG.

Widura, S. (2010). Be An Absolute Genius: Panduan Praktis Learn How To Learn Sesuai Cara Kerja Alami Otak. Jakarta: PT Elex Media Komputindo.

Widodo. (2013). Psikologi Belajar. Jakarta: PT Rineka Cipta.

Winkel. (2008). Psikologi Pengajaran. Jakarta: Gramedia Pustaka Tama.

Yanti, N. L. (2010) Psikologi Anak. Jakarta: PT. Macanan Jaya Cemerlang.

Yurisa. (2008). Metode Penelitian Keperawatan. Jakarta: PT. Macana Jaya Cemerlang.

Zuriah, N. (2008). Metodologi Penelitian Sosial dan Pendidikan, Teori Aplikasi. Jakarta: Bumi Aksara. 